\title{
Positive Evidence and Parameter Resetting in the Teaching of English Grammar to Libyan University Students
}

\author{
Aisha F. Abugharsa ${ }^{1}$ Fatma M. Elzawawi Majdi A. Zarmuh
}

Faculty of Arts - Misurata University

Received: 14-12-2020 Accepted: 04-01-2021 Available Online: 11-01-2021

https://doi.org/10.36602/faj/2021.n17.02

\begin{abstract}
This study builds on Chomsky's principles and parameters framework (Chomsky, 1986) by applying it to the study of second language (L2) acquisition. In other words, it makes use of a parameter resetting model to explain aspects of the second language learning process. It aims to investigate whether classroom instruction which presents only positive evidence, that is to say grammatically correct samples of the L2, is sufficient to enable adult second language learners to acquire certain properties of L2 parameters which differ from their mother tongue (L1). The participants in the study have Arabic as their L1, and are learning English as an L2. The study hypothesizes that the participants, who are all adult students studying English language at an advanced level in Misurata University, Libya, will not be able to reset the pro-drop parameter and the verb raising parameter from their properties in Arabic to their different properties in English. The hypothesized reason is that they are taught using only positive evidence-based samples of English, and that is not sufficient to lead to parameter resetting. The results show that the students had great difficulty in resetting the pro-drop parameter and the verb raising parameter from Arabic to English.
\end{abstract}

Keywords: Parameter resetting, Positive evidence only, Pro-drop parameter, Verb-raising parameter.

a.abugharsa@art.misuratau.edu.ly ${ }^{1}$ 


\section{الأدلة الإيجابية وإعادة ضبط المتغيرات في تدريس قواعد اللغة الإنكليزية}

\section{لطلاب الجامعات الليبية}

مجدي عبدالله الزرموح

فاطمة محمد الزواوي

عائشة فتحي أبوغرسة كلية الآداب - - جامعة مصراتة

\section{ملخص البحث}

تستند هذه الدراسة إلى المبادئ والإطار العملي للمعايير التي نادت بها نظرية (تشومسكي) عام1986، وذلك من خلال تطبيقها على دراسة اكتساب اللغة الثانية. وبمعنى آخر، فإنها تستخدم نموذج إعادة ضبط العوامل المتغيرة لشرح جوانب عملية تعلم اللغة الثانية. وتهدف هذه الدراسة إلى التحقق مما إذا كان تعليم الفصل الدراسي الذي يقدم دليلًا إيجابيًا فقط، أي عينات صحيحة نحويًا من اللغة الثانية، كافٍ لتمكين متعلمي اللغة الثانية البالغين من اكتساب خصائص معينة لمعايير اللغة الثانية التي تختلف عن لغتهم الأم (اللغة الأولى). وتشمل الدراسة متغيرين أثنين، هما متغير ارتفاع الفعل، ومتغير حذف الفاعل، ومّدف هذه الدراسة إلى اختبار مدى امكانية اسلوب التدريس المعتمد على تقديم التركيبات اللغوية الصحيحة- المساعدة في عملية اعادة ضبط المتغيرات بما يتناسب وقيمها الجديدة في اللغة الثانية. ولقد أظهرت نتائج الدراسة أن المشاركين واجهوا صعوبة كبية في اعادة ضبط العوامل المتغيرة من قيمها في لغتهم الأم إلى قيمها المختلفة في اللغة الإنكليزية التي يتعلموها. الكلمات المفتاحية: معايير تشومسكي، اكتساب اللغة الثانية، نموذج إعادة ضبط العوامل. 


\section{Introduction}

The concept of Universal Grammar, Chomsky (1986) has led to a number of important theoretical and empirical advances in the field of second language acquisition research. 'One of the most promising of these has been the advancement of a principles and parameter setting model in efforts to explain the L2 learning process' (Flynn 1996, p. 121). According to Flynn, the importance of adopting a Universal Grammar approach to explain the process of second language acquisition is that it is 'the most explicit theory of the human capacity for language and its acquisition...UG attempts to define the principles and conditions that are elements or properties of all natural languages' (p.123).

However, researchers in the field of L2 acquisition have different points of view concerning the role of Universal Grammar in this domain. They are divided into three groups concerning the role of UG in second language acquisition. White (1996, pp. 90-91) defines these three different views as 'full access', 'partial access' and 'no access' to Universal Grammar. Scholars who take the 'full access' view of the role of UG in L2 acquisition, believe that 'L2 learners often end up with highly..complex unconscious mental representations of their L2'. On the contrary, arguments favoring the 'no access' role of UG in second language acquisition are based on the recognized differences between L1 and L2 acquisition, taking the difficulties faced by adult L2 learners in acquiring a second language as evidence. Those who take this view assert that adult L2 learners "violate UG principles, and that developmental stages cannot be accounted for in terms of parameter resetting' (ibid, p. 91)

\subsection{The Research Objectives}

This study focuses specifically on the ability of L2 learners to reset the pro-drop parameter and the verb raising parameter, which 
have different values in Arabic and English. The participants are 20 students studying Advanced Grammar in the Department of English in Misurata University, Libya. They were randomly chosen and asked to give written responses to two grammaticality judgment tasks. These tasks are 'elicitation technique[s] where the test taker is presented with correct and incorrect language items and is expected to decide whether they are acceptable or not' (Seliger and Shohamy 1989, p. 177)

The first GJ task was designed to test whether the participants were able to reset the pro-drop parameter from its value in their first language (Arabic is a pro-drop, or null-subject, language) to its value in English (which is a non-pro-drop, or non-null-subject, language). As Cook (1996, p. 31) explains, 'in pro-drop languages such as Italian, Chinese or Arabic, the subject does not need to be actually present; [while] in non-pro-drop languages such as English or German, it must always be present in declarative sentences'. Arabic is a pro-drop language, which permits null-subject sentences because it has 'a rich set of inflectional endings on the verb...[which] permits information concerning the nature of the subjects...to be retrieved' (Goodluck 1991, p. 81).

The second task was designed to test whether the subjects were able to reset the verb raising parameter from Arabic to English. The value of this parameter in English is that 'main verbs in English cannot raise to I [Inflectional phrase]. Verb raising means moving (or raising) the verb to a higher position in the [phrase structure] tree' (Smith 1999, p. 126). This parameter is associated with a number of properties such as adverb, negation and quantifiers placements within the sentence. The task elicited the participants' judgments of English sentences, which have adverbs inserted between the main verb and its direct object. This is not grammatically correct in English, as it does not allow main verb raising or moving to this position in the sentence.

Poole (2002, p. 276) explains that main verbs in English can follow an adverb but may not precede one. It is ungrammatical to put 
an adverb between the main verb and its object. For example, the sentence Mary often sees Hailey is grammatical in English, while the sentence Mary sees often Hailey is not grammatical. In the second sentence, the main verb sees raises over the adverb often, which puts this adverb between the verb sees and its object Hailey, which, as mentioned before, is not grammatical in English. Ellis (1997, pp. 6667) wonders whether it is possible, on the basis of positive evidencebased input only, for second language learners to recognize that English does not permit an adverb between the verb and its direct object. He argues that they will also need to be presented with negative evidence showing the ungrammatical SVAO structure in English.

\subsection{The Research Problem}

This study aims to explore a number of issues concerning the availability of Universal Grammar to adult second language learners who share Arabic as their first language. In other words, it aims to explore the second language grammatical competence of the target group of adult learners in a Libyan university. Their access to Universal Grammar will be proved depending on whether or not they are able to reset parameters from their values in their first language to different values in the second language. The teaching techniques used in teaching English grammar to these students, and in the Department of English in general, are based, in most cases, on presenting positive evidence only. In other words, the materials and methods of instruction used in the English grammar classroom focus on presenting and teaching English grammatical structures in their correct forms (positive evidence), without in most cases using nongrammatical examples of the L2 to highlight areas of structural difficulty (negative evidence).

\subsection{The Research Hypothesis}

The study hypothesizes that providing adult L2 learners with positive evidence input of the target language will not be sufficient for 
parameter resetting in cases where the first and the target languages have different values of the same parameter. The study assumes that adult Arabic learners of English as a second language, even at an advanced level, will have difficulty in resetting the pro-drop parameter and the verb raising parameter unless they are provided with positive and negative evidence input together in the language classroom.

In addition, there is the issue of whether the results will show a difference in the resetting process of the two different parameters included in the study. It is hypothesized here that the participants might be able to reset one parameter and not able to reset the other, depending on the extent to which the differences between the L1 and L2 values are clear or not. The study hypothesizes that in some cases the difference between the two values of the same parameter will be so clear for L2 learners that they do not need to see negative evidence to help them in the parameter resetting process.

\subsection{The Research Questions}

1. Will adult Arabic ESL learners be able to reset two UG parameters (the pro-drop parameter and the verb-raising parameter) from their properties in Arabic to their different properties in English?

2. Will classroom instruction based on presenting only positive evidence be sufficient to build grammatical competence in the target language where parameters need to be reset from L1 values to different L2 properties?

3. Will the same participants be able to reset one parameter and not able to reset the other? Will some parametric properties be easier for L2 learners to reset than other properties associated with different parameters?

\subsection{Related Studies}

There has been a number of studies which have addressed the issue of parameter resetting for second language learners in cases where the first and second languages have different values of the same 
parameter. Among these studies are some which have investigated the acquisition of non-pro-drop or obligatory subject languages by speakers of first languages which are pro-drop or null-subject languages.

For example, White (1986) investigated whether L2 learners start by applying pro-drop parameter properties from the L1 setting to the L2 setting and then gradually learn to reset these properties to the L2 setting. Her study involved a mixed group of learners of English as a second language who have different pro-drop settings in their first languages. This mixed group included 37 French speakers (non prodrop L1 like English), 32 Spanish and 2 Italian speakers (pro-drop L1 different from the situation in English). White used grammaticality judgment tasks in which she used some English sentences without subjects as one of the procedures. At the end of this study, White found that the Spanish Italian pro-drop group performed less well on the task than the French non-pro-drop group, and concluded that the L1 pro-drop parameter influenced acquisition of the L2 non pro-drop parameter.

Another study by Tsimpli and Roussou (1991) on the pro-drop parameter resetting of Greek learners of English as a second language came to a similar conclusion. They found that speakers of the pro-drop Greek language have difficulty in resetting the parameter when learning English, which is a non-pro-drop language. They also used grammaticality judgment tasks as a tool to test whether the participants were able to reset this parameter or not. The results of this study indicated that the participants recognized English declarative sentences without subjects as ungrammatical.

Concerning the verb raising parameter, 'most research related to V-movement parameter has examined data from L2 learners of French who share English as an L1 or, conversely, L2 learners of English who share French as an L1' (Mandell 1999, p. 82). The reason behind this is that French, like Arabic which is the first 
language of the participants in our study, allows verb raising while English does not, which means that the two languages have different values of the same parameter.

Trahey and White (cited in Ellis 1997, pp. 85-86) designed a study in which they tested whether French learners of English as a second language were able to reset the verb raising parameter as a result of their being flooded with input containing sentences of the structure subject-adverb-verb-object (SAVO). In other words, the participants were presented with positive evidence only by being introduced to the target grammatical structure without being told that it is ungrammatical in English to form sentences with the order SVAO. The results of their study showed that the positive evidence only was partly useful as the participants showed an increase in using the structure SAVO.

Muftah and Wong (2014, p. 195) had similar results with Arabic learners of English who "even at ultimate attainment level, have great difficulty in resetting the parameterized property associated with the verb movement". They conclude that this is due to the fact that 'English and Arabic differ in the settings they adopt for the verb movement parameter... [consequently] the placement of the verb with respect to negation, adverbs, and floating quantifiers in English are considered difficult to acquire for adult Arabic ESL learners'.

\section{Methodology}

\subsection{Research Design}

The study based on the Quantitative approach for analyzing data by using Microsoft Excel (version 97-2003). This is to illustrate different descriptive data needed for the study.

\subsection{The Research Context and Participants}

The participants in this study are 20 adult students studying in the department of English in Misurata University, Libya. They are all 
native speakers of Arabic and their ages range between 20-24. They were a mixed group. This group of students were enrolled in the $3^{\text {rd }}$ Semester of their study in the academic year 2019-2020.and the study was conducted during the students' regular class on the Advanced Grammar Course. Because of their advanced level, they were expected to have a good competence of English Grammar, having already finished Grammar 1 and Grammar 2.

\subsection{Research Instruments}

The study used two grammaticality judgment tasks to elicit the participants' intuitions about the grammaticality of the English structures under investigation. The first task asked the students to accept or reject a set of English declarative sentences as 'GOOD' or 'BAD'. The set included some sentences which were ungrammatical because the subject was missing. The second task also consisted of a set of sentences some of which were ungrammatical, with the verb raised over an adverb in the order subject verb adverb and object. Each of the two tasks consisted of 12 sentences among which were ungrammatical for reasons unrelated to the purpose of this study. For example, among the twelve sentences in task 1 , there are only six sentences designed to test resetting of the pro-drop parameter, and in task 2 there are only five sentences designed to investigate resetting of the verb raising parameter.

The purpose of including unrelated items in every grammaticality judgment task was to hide the real focus of the investigation from the participants, which may have affected the elicitation of spontaneous intuitions. Birdsong (1989, p.122) insists on the usefulness of this procedure by explaining that 'when the investigator wishes to elicit spontaneous unadjusted responses, it may be desirable to prevent subjects from recognizing this focus', by including dummy items or distracters in the task. 


\subsection{Data Collection and Analysis}

The study was conducted during students' regular class of Advanced Grammar Course. The test was distributed to students and they were given one hour to answer the two judgment tasks.

The participants were instructed to explain the reasons behind their judgments whenever they rejected a sentence. They were asked to explain why they considered each sentence as ungrammatical. This was to test whether their knowledge of English grammar was conscious enough to enable them to explain their judgments and whether their explanations would actually give the real reason why each structure was ungrammatical. They were given one point (1) per correct answer i.e. one point for each ungrammatical structure that was correctly rejected. They were given no points (0) if they accepted an ungrammatical structure as being correct. A sentence was considered grammatical if it had the parametric values of English, and ungrammatical if it did not.

The data of the study was clarified through tables and bar charts by using Microsoft Excel (version 97-2003). The descriptive statistics with percentages were illustrated as shown below.

\section{Results}

\subsection{Task 1}

The scores achieved by the students are illustrated in Table 1 where it can be noticed that these scores are quite varied. 
Table 1: Scores obtained by the subjects in Grammaticality Judgment Task 1-pro-drop parameter

\begin{tabular}{|c|c|c|c|c|c|c|c|}
\hline Sentence & 3 & 6 & 7 & 9 & 11 & 12 & \multirow{2}{*}{$\begin{array}{c}\text { percentage of } \\
\text { correct rejections }\end{array}$} \\
\hline \multicolumn{7}{|l|}{ Student } & \\
\hline 1 & 1 & 1 & 1 & 0 & 0 & 0 & $50.00 \%$ \\
\hline 2 & 0 & 1 & 0 & 0 & 0 & 1 & $33.33 \%$ \\
\hline 3 & 1 & 0 & 0 & 0 & 0 & 0 & $16.67 \%$ \\
\hline 4 & 0 & 0 & 0 & 1 & 1 & 0 & $33.33 \%$ \\
\hline 5 & 0 & 0 & 0 & 0 & 0 & 0 & $0.00 \%$ \\
\hline 6 & 0 & 0 & 0 & 0 & 1 & 0 & $16.67 \%$ \\
\hline 7 & 0 & 1 & 0 & 1 & 1 & 0 & $50.00 \%$ \\
\hline 8 & 0 & 0 & 0 & 0 & 1 & 1 & $33.33 \%$ \\
\hline 9 & 0 & 0 & 0 & 0 & 0 & 1 & $16.67 \%$ \\
\hline 10 & 0 & 0 & 0 & 1 & 0 & 0 & $16.67 \%$ \\
\hline 11 & 0 & 0 & 1 & 0 & 1 & 0 & $33.33 \%$ \\
\hline 12 & 0 & 0 & 0 & 0 & 0 & 0 & $0.00 \%$ \\
\hline 13 & 1 & 1 & 0 & 0 & 0 & 1 & $50.00 \%$ \\
\hline 14 & 0 & 1 & 0 & 1 & 0 & 0 & $33.33 \%$ \\
\hline 15 & 1 & 0 & 0 & 0 & 0 & 1 & $33.33 \%$ \\
\hline 16 & 1 & 1 & 1 & 1 & 0 & 1 & $83.33 \%$ \\
\hline 17 & 0 & 1 & 0 & 1 & 0 & 0 & $33.33 \%$ \\
\hline 18 & 0 & 1 & 0 & 0 & 0 & 1 & $33.33 \%$ \\
\hline 19 & 0 & 1 & 0 & 0 & 0 & 1 & $33.33 \%$ \\
\hline \multirow[t]{2}{*}{20} & 0 & 1 & 0 & 0 & 1 & 0 & $33.33 \%$ \\
\hline & $25 \%$ & $50 \%$ & $15 \%$ & $30 \%$ & $30 . \%$ & $40 \%$ & \\
\hline \multicolumn{7}{|c|}{ Average } & $31.7 \%$ \\
\hline
\end{tabular}

To have a clear idea about the frequency of the scores achieved by the subjects in this task, Table 2 shows the frequency distribution for each score obtained in the task. It can be noticed from this table that the majority of the students (15 students) achieved lower than $50 \%$; (10 students obtained $33.33 \%$ and 4 students obtained $16.67 \%$ ). Only 3 students achieved $50 \%$ while just one student achieved the highest score $83.33 \%$. The average score obtained by the subjects in this task is $31.7 \%$. 
Table 2: Frequency distribution for scores on Grammaticality Judgment Task 1

\begin{tabular}{lcc}
\hline Score & Students & \\
\hline $0 \%$ & $5-12$ & 2 students \\
$16.67 \%$ & $3-6-9-10$ & 4 students \\
$33.33 \%$ & $2-4-8-11-14-15-17-18-19-20$ & 10 students \\
$50 \%$ & $1-7-13$ & 3 students \\
$83.33 \%$ & 16 & 1 student \\
\hline
\end{tabular}

The variation in the scores obtained by the participants suggests that their judgments were to a certain extent inconsistent. However, these results indicate that most of them were not able to reset the pro-drop parameter from Arabic, which is a pro-drop language, to English, which is not- In most cases the results show that the participants did not know that it is not grammatical to have declarative sentences without subjects in English. The participants were also asked to explain the reasons behind their judgments, as these explanations would be considered to indicate their having an explicit conscious knowledge of the target language grammar. Surprisingly, all the participants, despite their advanced level in studying grammar, were not able to give any explanation of why they rejected particular sentences in this task. The following chart (figure 1) shows the percentages of correct rejection for each of the six ungrammatical sentences in task 1 . 


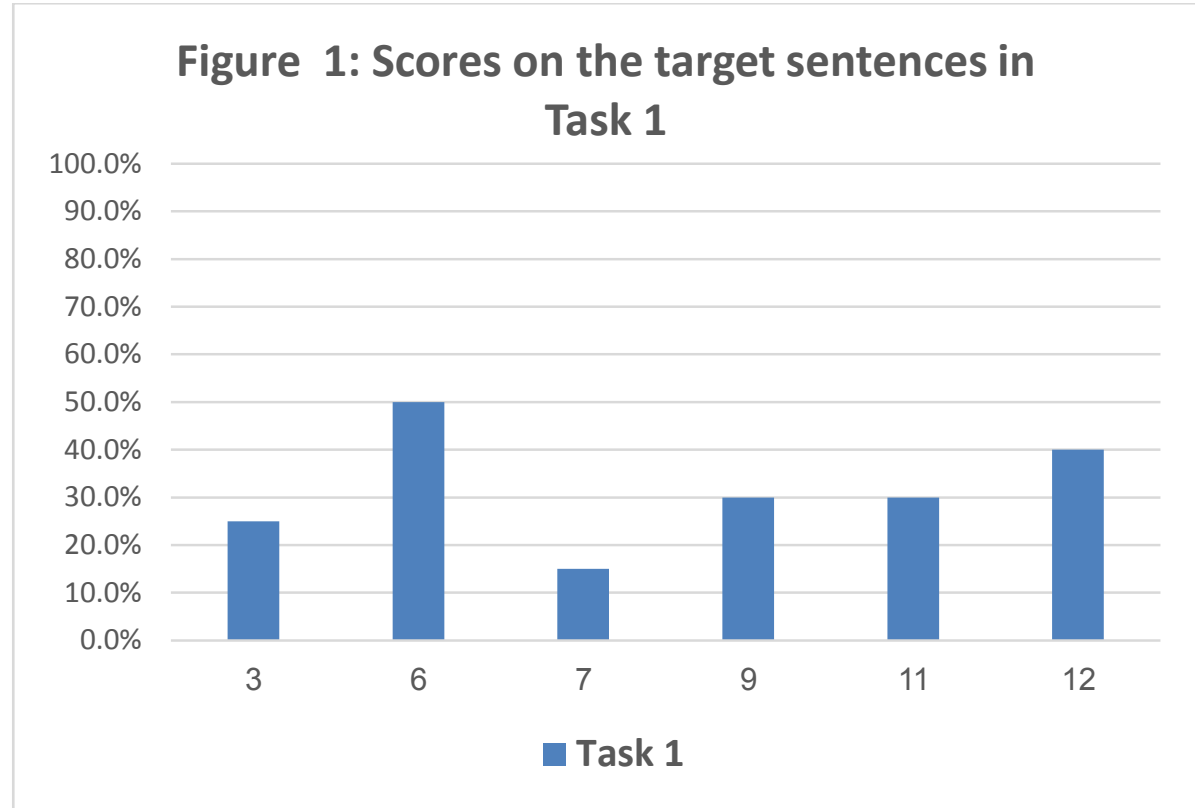

By having a look at figure 1, it can be seen that the six target sentences have got a similar percentage of correct rejections which is lower than $60 \%$. The overall percentage for sentence $6 *$ People always wonder if is easy to please John is $50 \%$, which is the highest of the five target sentences. This means that 10 students judged it correctly as bad, and 10 students accepted it as a well-formed sentence. However, no one was able to give an explanation of why they rejected the sentence, which means that they felt that this sentence lacks something, but they were not able to explain why. This situation was the same for all six target sentences.

Sentence 6 together with sentence $12 *$ John and Mary said that helped each other have got the highest percentage of rejections overall compared to the other target sentences. Sentence 12 was rejected by 8 students ( $40 \%$ of the total number of students), while 12 students accepted it as a well-formed sentence.

Sentences $9 *$ In winter, snows a lot in Canada and $11 *$ John told Lucy that is going to go to china got the same percentage of rejections overall which is $30 \%$. This means that only 7 students 
rejected these sentences and 13 accepted them wrongly as wellformed ones.

Sentences $3 *$ Because of modern transportations, easy for us to get there very quickly and $7 *$ Works hard to get enough money got the lowest percentage of correct rejection compared to the other target sentences. Most of the students (75\%) judged sentence 3 wrongly as good despite the fact that it lacks the dummy pronoun it as a subject, while only 6 students correctly rejected this sentence.

Sentence 7 has the lowest overall score which is $15 \%$ as only 3 students rejected this as an ungrammatical sentence.

The performance of the participants on grammaticality judgment task 2 was no better than their performance on task 1. Task 2 was designed to test whether the subjects had already reset the verbmovement parameter to its different value in English. The target sentences in this task contained a wrong placement of adverbs between the lexical verb and the object NP which cannot appear in English because the verb cannot be raised out of the verb phrase. The appearances of adverbials in this position is evidence that the verb has moved from the head of the VP to the head of the tense phrase which is not possible in English. The task consisted of 12 sentences among which five sentences included ungrammatical movement of English main verbs, while the other sentences were included in the task as dummy items.

In a similar procedure that used for task 1, the participants were given one point (1) for each correct rejection of any of the five target sentences and were given (0) point for incorrect acceptance. The scores obtained are illustrated in Table 3 -where, as was done with task one, the percentages of their correct rejections of the five sentences are considered as their scores in the task. 


\subsection{Task 2}

Table3: Scores obtained by the subjects in Grammaticality Judgment

Task 2-verb raising parameter

\begin{tabular}{|c|c|c|c|c|c|c|}
\hline Sentence & 2 & 4 & 6 & 7 & 11 & \multirow{3}{*}{$\begin{array}{c}\text { percentage of } \\
\text { correct rejections }\end{array}$} \\
\hline & & & & & & \\
\hline \multicolumn{6}{|l|}{ Student } & \\
\hline 1 & 1 & 1 & 0 & 0 & 1 & $50.00 \%$ \\
\hline 2 & 0 & 0 & 0 & 0 & 0 & $0.00 \%$ \\
\hline 3 & 1 & 0 & 0 & 0 & 0 & $16.67 \%$ \\
\hline 4 & 1 & 1 & 1 & 1 & 0 & $66.67 \%$ \\
\hline 5 & 1 & 1 & 0 & 0 & 0 & $33.33 \%$ \\
\hline 6 & 0 & 0 & 0 & 0 & 0 & $0.00 \%$ \\
\hline 7 & 0 & 0 & 0 & 1 & 0 & $16.67 \%$ \\
\hline 8 & 0 & 0 & 0 & 1 & 0 & $16.67 \%$ \\
\hline 9 & 1 & 0 & 0 & 0 & 0 & $16.67 \%$ \\
\hline 10 & 0 & 1 & 0 & 0 & 0 & $16.67 \%$ \\
\hline 11 & 0 & 1 & 0 & 1 & 1 & $50.00 \%$ \\
\hline 12 & 0 & 0 & 0 & 1 & 0 & $16.67 \%$ \\
\hline 13 & 0 & 0 & 0 & 1 & 0 & $16.67 \%$ \\
\hline 14 & 0 & 0 & 0 & 1 & 0 & $16.67 \%$ \\
\hline 15 & 1 & 0 & 0 & 0 & 0 & $16.67 \%$ \\
\hline 16 & 0 & 1 & 1 & 0 & 1 & $50.00 \%$ \\
\hline 17 & 0 & 0 & 0 & 0 & 1 & $16.67 \%$ \\
\hline 18 & 0 & 0 & 0 & 0 & 1 & $16.67 \%$ \\
\hline 19 & 0 & 0 & 0 & 1 & 1 & $33.33 \%$ \\
\hline \multirow[t]{3}{*}{20} & 0 & 1 & 0 & 1 & 0 & $33.33 \%$ \\
\hline & $30 \%$ & $35 \%$ & $10 \%$ & $45 \%$ & $30 \%$ & \\
\hline & & & & & Average & $25.0 \%$ \\
\hline
\end{tabular}


As can be seen in the following table, the frequency distribution of the results shows that the scores achieved in this task are lower than the scores obtained in the previous task. In fact, the average score for this task was only $25.0 \%$. It can also be observed that the scores obtained in this task are quite variable.

Table 4: Frequency distribution for scores on Grammaticality Judgment Task 2

\begin{tabular}{lcc}
\hline Score & Students & \\
\hline $0 \%$ & $2-6$ & 2 students \\
$16 \%$ & $3-7-8-9-10-12-13-14-15-17-18$ & 11 students \\
$33 \%$ & $5-19-20$ & 3 students \\
$50 \%$ & $1-16-11$ & 3 students \\
$66.67 \%$ & 4 & 1 student \\
\hline
\end{tabular}

\section{Figure 2: Scores on the target sentences in} Task 2

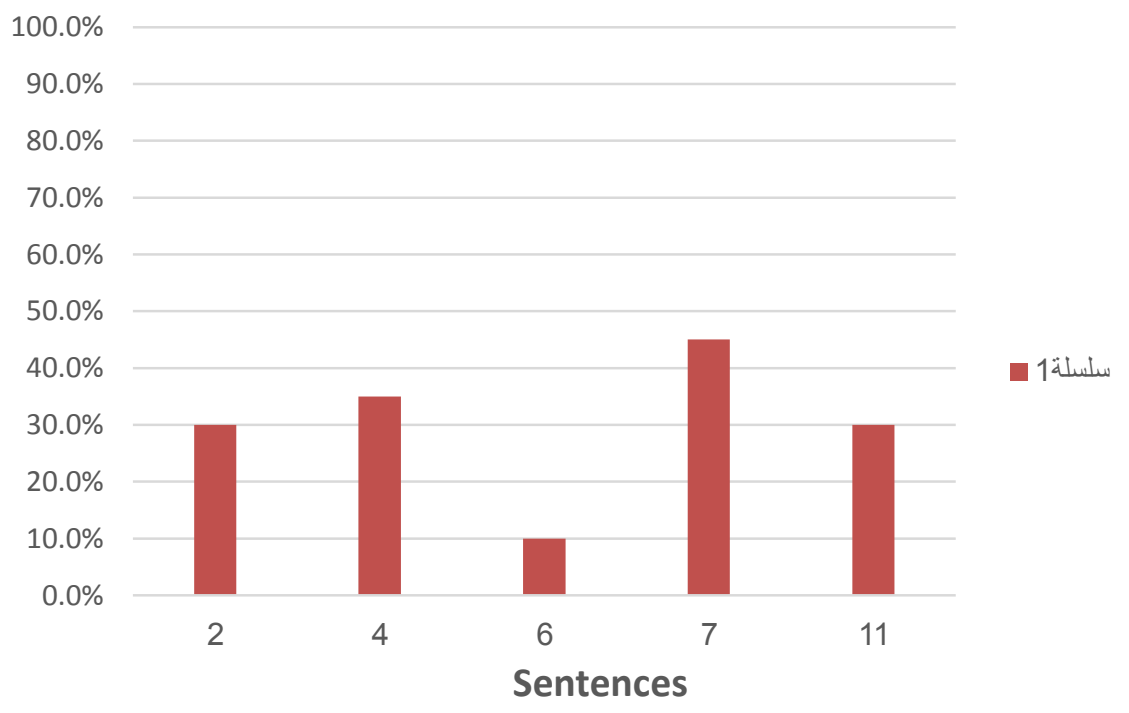


As shown in Figure 2, sentence $7 *$ John and Mary wrote a book about children. It helps always many parents to deal with their kids got the highest percentage of incorrect responses compared to the other four target sentences. It was rejected by $45 \%$ of the participants, meaning that only 9 out of the students rejected it as grammatically wrong, while 11 students accepted it as a well-formed sentence.

There seem to be similarities and agreements in the participants' answers to this task as can be noticed in the students' responses for sentences $2 *$ Mary ate rapidly her dinner and went to the movies, $4 * I$ ate an apple and John ate quickly a pear, and sentence 11 *Jack drives fast his car with no attention to the traffic lights. Only $6(30 \%)$ of the participants correctly rejected sentences 2 and 11 while 14 students considered them as grammatically wellformed sentences. Similarly, only 35\% correctly rejected sentence 4 while $65 \%$ accepted it. None of the participants was able to provide any explanation of why they rejected any sentence. The lowest number of correct responses recorded for sentence 6 *Our teacher is very skillful. She explains slowly the lesson to make sure that everybody understands it. This was rejected as ungrammatical by only $10 \%$ of the participants. It can be concluded then that most of the students were not able to recognize that the sentence was incorrect.

\section{Discussion}

Concerning the argument about whether the participants would able to reset one of the parameters and not the other, figure 3 compares the performance of each participant in the two grammaticality judgment tasks. It appears that the performance on the two tasks was similar for most of the students, which suggests that they were not able to reset these two parameters from Arabic to English. However, the performance on grammaticality judgment task 1 , which tested resetting of the pro-drop parameter, was in some cases a little bit better than the performance on task 2 which tested resetting of the verb raising parameter. This may suggest that the idea that all 
declarative English sentences, unlike Arabic sentences, must have subjects was clearer and more easily noticed and acquired by the participants despite being exposed to only positive evidence-based input. On the other hand, the positive input showing that adverbs must be placed before the main verb in English sentences appears not to have been sufficient for the participants to know that it is not grammatical to put the verb before the adverb. For this reason, the performance on the pro-drop parameter was better than the performance on verb-raising. However despite this, it may be said that the participants' performance on both tasks was not good enough to conclude that they were able to reset either of the two parameters.

\section{Figure 3: Scores on task 1 and task 2 per student}

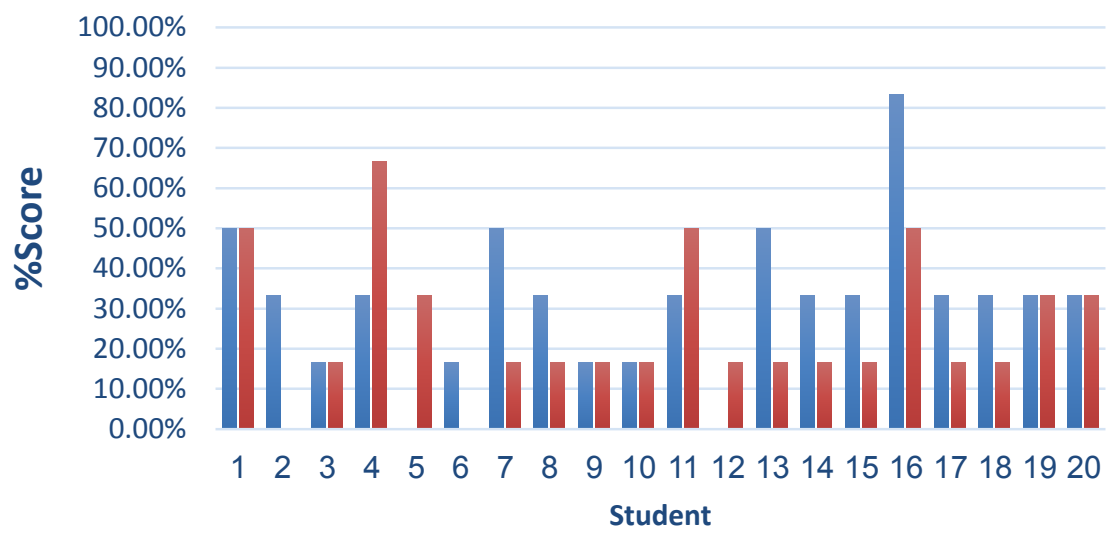

- Task 1 Task 2

\section{Conclusion}

As was hypothesized, the results of this study show that the participants were not successful in resetting the pro-drop parameter and the verb raising parameter from their properties in Arabic to their 
different properties in English. The scores that the participants obtained in the two grammaticality judgment tasks were not good enough to indicate that they were able to reset these parameters from L1 to different L2 values. This suggests that classroom instruction based on presenting grammatical or positive evidence input of the target language is insufficient to build a grammatical competence of the target language as a result of parameter resetting.

The performance on the pro-drop parameter task was a little better than the performance on the verb raising parameter. This suggests that the importance of having a subject in any declarative English sentence was clear to some of the participants after years of exposure to grammatical English sentences. On the other hand, positive evidence input which includes grammatical English sentences of the order SAVO 'does not show learners that forms like SVAO are ungrammatical' (Ellis 1997, p. 86). This may explain why the scores obtained on task 2 were lower than the scores obtained on task 1 by most of the participants.

\section{Recommendation}

These results shed light on the teaching of grammar in the Department of English in Misurata University, and suggest that some changes of approach might be beneficial. In particular, including some negative evidence in classroom instruction may help learners to become more conscious of structural differences between Arabic and English, as it has been shown that positive evidence alone is not sufficient to lead to parameter resetting from Arabic values to the different English values. Based on this study, it is also recommended that grammaticality judgment tasks should be used to test students' competence in the target language in addition to the other means of testing which are already used. 


\section{References}

Birdsong, D. (1989) Metalinguistic Performance and Interlinguistic Competence. Springer.

Chomsky, N. (1986) Knowledge of Language: its Nature, Origin, and Use. Praeger.

Cook, V. (1996) Second Language Learning and Language Teaching. $2^{\text {nd }}$ edn. Arnold.

Ellis, R. (1997) Second Language Acquisition. University Press.

Flynn, S. (1996) A Parameter Resetting Approach to Second Language Acquisition in Ritchie, C \& Bhatia, T (eds) Handbook of Second Language Acquisition. Academic Press: 121-158.

Goodluck, H. (1991). Language Acquisition: a linguistic introduction. Blackwell Publishers.

Mandell, P. (1999) On the reliability of grammaticality judgment tests in second language acquisition research. Second Language Acquisition Research. 15 (1): 73-99.

Muftah, M. \& Wong, E. (2014) Acquisition of the Verb Movement Parameter in English by Adult Arabic Speakers. Social Sciences and Humanities. 22(1) 195-215.

Poole, G. (2002) Syntactic Theory. Palgrave

Seliger, H \& Shohamy, E. (1989) Second Language Research Methods. Oxford University Press. 
Smith, N. (1999) Chomsky: ideas and ideals. Cambridge University Press.

Tsimpli, I \& Roussou, A. (1991) Parameter Resetting in L2? UCL Working Papers in Linguistics. 3: 149-169.

White, L. (1986) Implications of Parametric Variation for Adult Second Language Acquisition: an Investigation of the Prodrop Parameter in Cook, V (ed) Experimental Approaches to Second Language Acquisition. Pergamon Press

White, L. (1991) Adverb Placement in Second Language Acquisition: some effects of positive and negative evidence in the classroom. Interlanguage Studies.7 (2), 133-161.

White, L. (1996) Universal Grammar and Second Language Acquisition: Current Trends and New Directions in Ritchie, C \& Bhatia, T (eds) Handbook of Second Language Acquisition. Academic Press: 85-116. 